\title{
Derivational Suffixes in Crazy Rich Asians Novel: A Morphological Analysis
}

\author{
Ni Putu Dian Narasuari*, Ni Ketut Sri Rahayuni \\ English Department, Faculty of Arts, Udayana University \\ [narasuaridian@gmail.com],[ketutsrirahayuni@gmail.com] \\ Denpasar, Bali, Indonesia \\ *Corresponding Author
}

\begin{abstract}
This study focused on the classification types and identifying the function of derivational suffixes. The data were taken from a novel entitled Crazy Rich Asians by Kevin Kwan. The collected data were analysed by using documentation method and qualitatively analyzed. The analysis was based on the theory of morphological study, particularly suffixes that is proposed by Plag (2002:109). Moreover, Merriam Webster dictionary is used in this study to analyse the word class of suffixes. The findings showed that there are four types of suffixes, such as: nominal suffixes, verbal suffixes, adjectival suffixes, adverbial suffixes. The function of the suffix can be divided into two, which is to class maintaining suffixes and class changing suffixes.
\end{abstract}

Keywords: derivational, suffixes, novel

\begin{abstract}
Abstrak
Studi ini berfokus pada pengelompokan tipe dan mengidentifikasi fungsi akhiran derivasi. Data tersebut diambil dari sebuah novel yang berjudul Crazy Rich Asians oleh Kevin Kwan. Data yang dikumpulkan dianalisa dengan menggunakan metode dokumentasi dan metode kualitatif. Analisis ini berdasarkan teori studi morfologi, khususnya akhiran yang dipaparkan oleh Plag (2002: 109). Selain itu, kamus Merriam Webster digunakan dalam penelitian ini untuk menganalisis kelas kata akhiran. Dalam analisis ini terdapat empat jenis akhiran, seperti: akhiran kata benda, akhiran kata kerja, akhiran kata sifat, akhiran kata keterangan. Fungsi akhiran dapat dibagi menjadi dua, yaitu untuk akhiran yang mempertahankan kelas dan akhiran yang mengubah kelas.
\end{abstract}

Kata kunci: derivasional, akhiran, novel

\section{INTRODUCTION}

English has an important role in the world as a mean of international communication. To understand the use of English well, we have to know about the aspects of the language. In linguistics, there are several aspects of language that we need to understand, one of them is morphology. In morphology we study about word formation. (Wulandari, 2014: 2) stated that morphology is a linguistic study of word formation that has a relation with other words. Katamba (1993:19) stated, "Morphology is the study of word structure". Based on those definitions, it can be concluded that morphology is the study of morphemes and their arrangement into words. 
Furthermore, Katamba (1993:47), stated "Derivational morphemes form is new words either by changing the word class that a base belongs to or by changing the base which it is attached". Therefore, the process of how a new word can be formed is named derivation. Derivational is one of the types word formation and word formation is characteristics of human language to create new words. There are types of derivational suffix such as; nominal suffixes, verbal suffixes, adjectival suffixes and adverbial suffixes.

Based on the introduction, this study aimed to analyse the types and function of suffixes in the Crazy Rich Asians novel by using the diagram and theory of suffixes that proposed by Plag (2002: 109).

\section{MATERIAL AND METHOD}

The data source of this study was Crazy Rich Asians novel written by Kevin Kwan. It is romantic comedy novel that published in 2013 with 425 pages. This novel tells about a love between a common girl and a wealthy man. A film adaption of Crazy Rich Asians novel was released on August 15, 2018.

In collecting the data, this study uses documentation method, accompanied by the note-taking technique. The data are collected by using following steps. Firstly, read the novel thoroughly to find the suffixes. Secondly, taking note from the data. Lastly, write down the data based on types of suffixes used in Crazy Rich Asians novel.

The data were analysed based on the scope of discussion using theory proposed by Plag (2002:109) consisting of types and function in this analysis and the results presented by using a descriptive qualitative. Furthermore, there are contribute of the definition of root, stem, and base were identified by using the concept proposed by Katamba (1993) and Katamba (1994).

Since this study find the word classes in the novel, Merriam Webster Dictionaries Online, and articles are used as the source of information.

\section{THEORETICAL BASIS}

\section{Literature Review}

There are journal articles reviewed that are related to derivational suffixes (Muthmainnah, 2014; Prasada, 2016; Mahendra, 2017) which discussed the form of suffixes by using the same theory and concepts to this study. Ariani (2017) discussed about the prefixes and suffixes in Batusesa Dialect of Balinese which belong to derivational and inflectional morpheme, but the techniques that used is different because the collecting data were taken by observation, recording and interview.

There are related articles which discuss about morphology, such as borrowing, compounding, reduplication and affixation (Robinson, 2016; Nur and Ainun, 2016). Moreover, relevant articles by (Ford, Davis, and Wilson, 2010) stated in their article mention about morpheme of the base, it is related but in this discussion not used visual lexical. Another article that shows the suffixes are productive in word formation by the process of derivational morphology (Fleta, 2011; Choi, 2015)

However, there are some articles that focused on one type of suffix that is derivational forming noun (Puspita, 2013; Sari, 2017; Manggala, 2018) and derivational forming adjective in newspaper article with the main theory used is proposed by Quirk (Jayanti, 2016). In addition, related articles that discussed the morphological suffix more broadly, including inflectional and derivational was Nurtiddini \& Soraya (2019). There are analysis of derivational 
suffixes which used the data source from junior high school (e.g Herman, 2015) and there are analysis that uses the data source from the students' scores in vocabulary test about derivational suffixes used in word formations. (e.g Utami, 2015).

\section{Suffixes}

Theory proposed by Plag (2002:109) states there are types of suffixes.

Nominal suffixes are usually used to form abstract nouns from verbs, adjectives and nouns, such as; -age, -al, ance, -ant, -cy/-ce, -dom, -ee, -eer, -er, ery, -ess, -ful, -hood, -an, -ing, -ion, -ism, -ist, -ity, -ment, -ness, -ship.

Verbal suffixes are derive verbs from other categories, mostly adjectives and nouns, such as; /-ate/, /-en/, /-ify/, /-ize/.

Adjectival suffixes are formed from nouns, verbs, adjectives, such as; -able, al, -ary, -ed, -esque, -ful, -ic, -ing, -ish, ive, -less, -ly, -ous.

Adverbial Suffixes is a word that modifies a verb, an adjective, or another adverb, such as; -ly, -wise.

The function of the suffixes can be divided into two, which is to class maintaining suffixes and class changing suffixes.

\section{RESULT AND DISCUSSION}

The discussion in this part are morphological analysis, namely derivational suffixes that proposed by Plag theory which is categorized into the types and explain the function of suffixes used in Crazy Rich Asians novel by diagram.

\section{Nominal Suffixes}

\section{Suffix /-age/}

This suffix derives nouns that express an activity (or its result), and nouns denoting a collective entity or quantity. Base words may be verbal or nominal.

For example:

\section{Data 1}

"Mom, we've never once talked about marriage," Rachel said, trying to downplay it. (Kevin Kwan, 2013: 23)

Analysis:

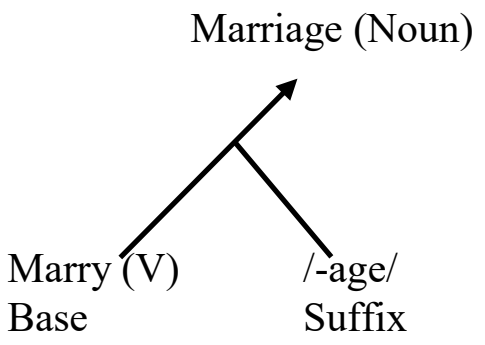

Example (1), shows of derivational suffixes. In the diagram explained clearly the word marriage is derived from the word marry as base or verb, and attached by suffix /-age/. Since, suffix /-age/ is only changing the base.

Function: Class-changing suffix (Verb forming Noun). Marry (V) $+/$-age/ $=$ Marriage $(\mathrm{N})$

\section{Suffix /-hood/}

Suffix -hood derivatives express concepts such as 'state' and 'collectivity'.

For example:

\section{Data 2}

This was the way things had been since their childhood as neighbours growing up on Serangoon Road. (Kevin Kwan, 2013: 17)

Analysis:

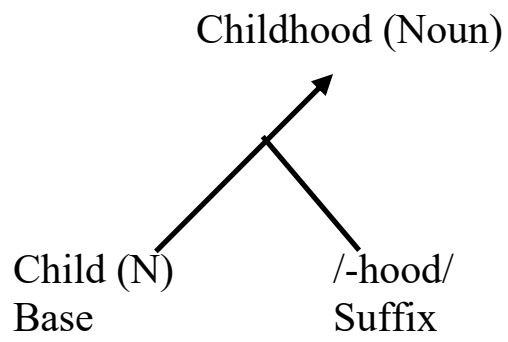


The word childhood is the new word derived from combination of word Child as noun and suffix /-hood/. Childhood is noun according to Merriam Webster dictionary. Suffix /-hood/ in the end of word childhood is not changing word class.

Function: Class-maintaining suffix (Noun forming Noun). Child (N) $+/$ hood $/=$ Childhood $(\mathrm{N})$

\section{Suffix /-ness/}

This suffix can attach to practically any adjective.

For example:

\section{Data 3}

Her mother was already far too invested in her happiness , and she didn't want to get her hopes up...too much.

(Kevin Kwan, 2013: 24)

Analysis:

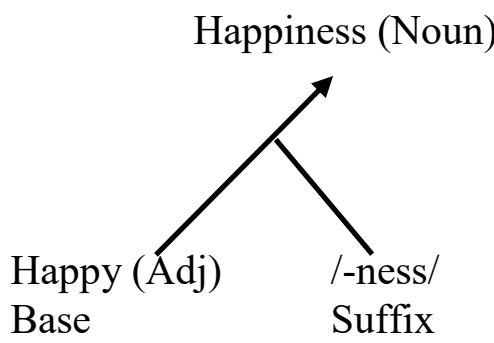

The word happiness can be determined as noun because according to Merriam Webster dictionary. The word happiness is derived from the word happy and attach by suffix /-ness/. Happiness comes from word happy as base and it categorized as adjective, taking suffix /-ness/ to produces new word happiness.

Function: Class-changing suffix (Adjective forming Noun). Happy (Adj) +/-ness/ = Happiness $(\mathrm{N})$

\section{Suffix /-ship/}

This suffix forms nouns denoting 'state' or 'condition', -ship from base word are mostly person nouns.

For example:

\section{Data 4}

It boasted the legendary gambling tycoon Stanley Lo as its honorary president, and its restrictive membership had an eightyear waiting list open only to the most established families. (Kevin Kwan, 2013: 36)

Analysis:

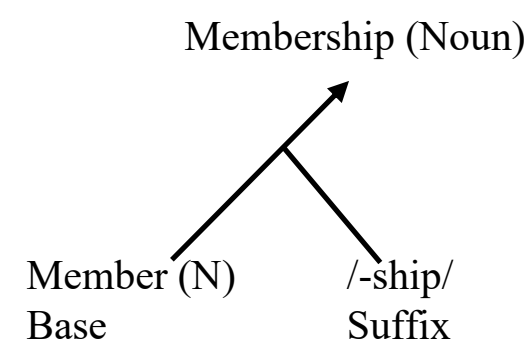

According to Merriam Webster dictionary, the word membership is noun. However, this deriving word is formed by the word member as the base word and noun which attached by suffix /-ship/ into noun.

Function: Class-maintaining suffix (Noun forming Noun). Member (N) + /ship/ = Membership (N)

\section{Verbal Suffixes}

\section{Suffix /-ize/}

Derivatives in suffix /-ize/ show rather complex patterns of base allomorph, to the effect that bases are systematically truncated.

For example:

\section{Data 5}

"Aiyah, Colin just wants to monopolize Nick for as long as possible," Araminta declared.

(Kevin Kwan, 2013: 91)

Analysis: 


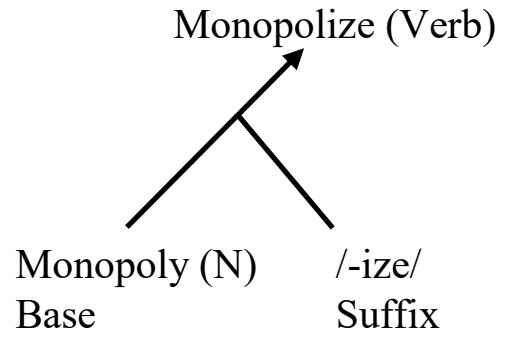

The word monopolize can be determined as verb, and this word attach by suffix /-ize/. Monopolize is derived from word monopoly as base and noun, taking suffix /ize/. The attachment of suffix /-ize/ at the end of word monopolize is changing the word class from noun into verb.

Function: Class-changing suffix (Noun forming Verb). Monopoly (N) + /ize/ = Monopolize (V)

\section{Adjectival Suffixes}

Suffix /-able/

This suffix described as "capable of being $X$ ' (readable) and 'liable or disposed to $\mathrm{X}^{\prime}$ (agreeable), characterized by X (fashionable).

For example:

\section{Data 6}

The only acceptable majors were medicine or law (unless you were truly dumb, in which case you settled for accounting).

(Kevin Kwan, 2013: 55)

Analysis:

Acceptable (Adjective)

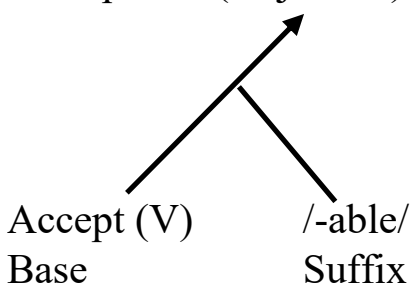

According to Merriam Webster dictionary, the word acceptable is adjective. Hence, the word accept belongs to acceptable is different word class or changing the lexical category. Accept is categorized as verb and the word acceptable as adjective.

Function: Class-changing suffix (Verb forming Adjective). Accept (V) + /-able/ = Acceptable (Adj)

\section{Suffix /al/}

This relational suffix attaches almost exclusively to Latinate bases.

For example:

\section{Data 7}

She hadn't seen this particular brand of superior sneer since she was a child growing up in the waning days of colonial Singapore.

(Kevin Kwan, 2013: 03)

Analysis:

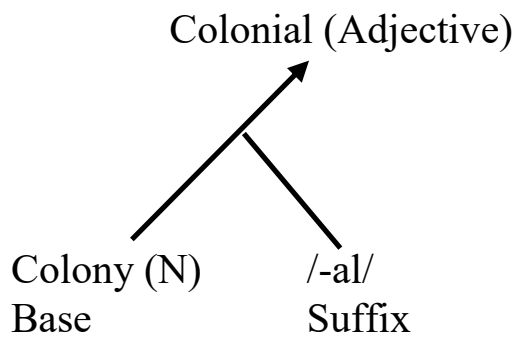

The example shows of derivational process. In the diagram explained clearly the word colonial is derived from the word colony as base, and attached by suffix /-al/. Since, suffix /-al/ is changing the base. Therefore, the word colonial belongs to adjective due to the adding of suffix /-al/.

Function: Class-changing suffix (Noun forming Adjective). Colony $(\mathrm{N})+$ /-al/ = Colonial (Adj)

\section{Suffix /-esque/}

The suffix -esque is attached to both common and proper nouns to convey the notion of 'in the manner or style of $X$ '. For example: 


\section{Data 8}

Rachel headed alone to the beach bar, a picturesque gazebo overlooking a secluded cove. (Kevin Kwan, 2013: 206) Analysis:

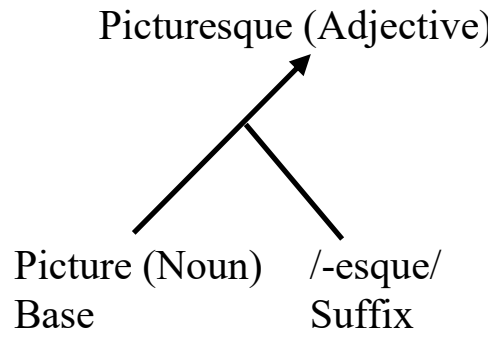

According to Merriam Webster, the word picturesque is adjective. However, this deriving word is formed by the word picture acts as the base word and noun class which attached by adjectival suffix /-ful/ into adjective class.

Function: Class-changing suffix (Noun forming Adjective). Picture (N) + /-esque/ = Picturesque $($ Adj)

\section{Adverbial Suffixes}

Suffixes -ly

Adverb are generally derived from an adjectival root which the suffix /-ly/ is added.

For example:

Data 9

The staff quickly snapped to attention, surprised to see the old lord, who hadn't set foot inside the hotel in years.

(Kevin Kwan, 2013: 07)

Analysis:

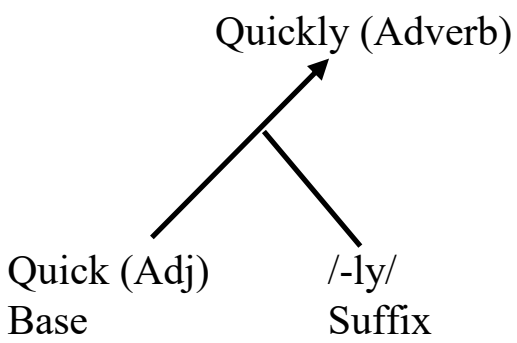

The word quickly in the diagram as adverb according to Merriam Webster dictionary. The word quick is derived from quick and suffix /-ly/ to produces new word quickly.

Function: Class-changing suffix (Adjective forming Adverb). Quick (Adj) $+/$-ly/ = Quickly (Adv)

\section{Suffix -wise}

This suffix made up of adverbs whose meaning can be rendered as "with respect to, in regard to, concerning $X$ '. Suffix - wise derives adverbs from nouns. For example:

Data 10

"Likewise," Sophie said, flashing that deep-dimpled smile again.

(Kevin Kwan, 2013: 209)

Analysis:

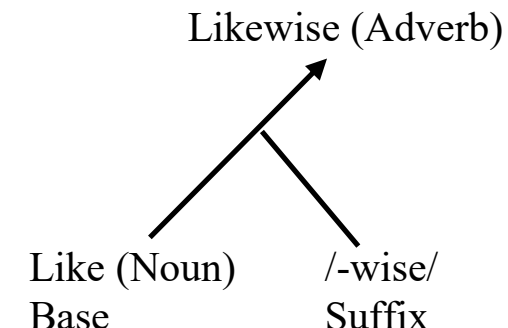

The word likewise is adverb according to Merriam Webster dictionary. The word likewise is derived from the word like, taking suffix /-wise/. Likewise comes from the word like as base that produce new word likewise. It is derivational process.

Function: Class-changing suffix (Noun forming Adverb). Like (N) + /wise $/=$ Likewise (Adv)

\section{CONCLUSION}

Based on the analysis, there are some points can be noted as the conclusion.

There are four examples of nominal suffixes found, such as /-age/, /-hood/, /ness/, and/-ship/. One example of verbal 
suffixes, such as /-ize/. Three examples of adjectival suffixes, such as /-able/, /al/, /-esque/. Two examples of adverbial suffixes, such as /-ly/, /-wise/.

The function of derivational suffix can be divided into two; they are classmaintaining suffix and class-changing suffix. There are several types of suffixes that have functions as class-changing suffixes such as; /-age/, /-ness/, /-ize/, /able/, /-al/, /-esque/, /-ly/, /-wise/. And types of suffixes that have functions as class-maintaining suffixes such as; /hood/, /-ship/.

\section{REFERENCES}

Choi, Y.H. (2015). Roles of L1 and L2 Derivational Morphological Awareness in L2 Reading Though the Mediation of L2 Vocabulary Knowledge. The Journal of Asia TELF, Vol.12.3. 81-114.

Fleta, B.M. (2011). Suffixes in wordformation processes in scientific English. LSP Journal, Vol.2.2. 0411.

Ford, M.A. Davis, M.H. Wilson, W.D. (2010). Derivational morphology and base morpheme frequency. Journal of Memory and Language, Vol.63.117-130

Herman. (2015). Suffixes Found In Narrative Writing At Grade Eight of SMP Methodist Pematangsiantar. IOSR Journal of Humanities and Social Science, Vol.20.4. 40-48.

Jayanti, N.S. (2016). The Derivational Adjectives in "The New York Times". Journal of Arts and Humanities, Vol.16.2. 152-158.
Katamba, F. (1993). Modern Linguistic Morphology. London: Macmillan press.Ltd

Katamba, F. (1994). English word. London: Routledge.

Komang, A. (2017). Derivational and Inflectional Prefixes and Suffixes in Batudesa Dialect of Balinese: A Descriptive Study. International Journal of Language and Literature, Vo.1.1. 42-50

Mahendra, D. (2017). Derivational English Suffixes with Reference to the Jakarta Post. Humanis, Vol.19.1.45-51.

Manggala, A. (2018). Derivational Noun in the Economist Magazine "The Trump Presidency So Far". Humanis, Vol.22.2. 447-452.

Muthmainnah, A. (2014). Teaching Derivational Suffixes to Improve the Vocabulary Mastery through Reading Text. English Language Teaching Society. Vol.2.1. 1-11

Nur, D.R and Ainul, K. (2016). An Analysis of Derivational Affixes in Commencemment Speech by Steve Jobs. Script Journal, Vol.1.1. 25-35.

Nurtidinni, D. Soraya, L. (2019). Morphological Suffixes in the Article of the Jakarta Post Online Newspaper. Professional Journal of English Education, Vol.2.2. 113119.

Plag. Ingo. (2002). Word-Formation in English. Cambridge University Press. 
Prasada, G. (2016). Derivational Suffixes in Bhagavad Gita. Humanis, Vol.16.3. $58-64$.

Puspita, H. (2013). Derivational English Suffixes Forming Noun in the Novel "Can You Keep a Secret?" by Sophie Kensella. Humanis, Vol.4.2. 1-8.

Robinson, N. (2016). Word formation: the Description of the Nyakyusa Derivation and Inflection. International Journal of Language and Linguistics, Vol.3.5. 62-71.

Sari, Y. (2017). Derivational English Suffixes Forming Noun With Reference to Condé Nast Traveller UK e-Magazine. Humanis, Vol.18.2. 96-104

Utami, S. (2015). The Students Ability in using Derivational Suffixes in word formation. Jurnal Cemerlang. Vol.3.1. 19-27

Wulandari, A. (2014). A Morphologycal Analysis of Derivational Suffixes in Short Stories. Article Publication, Vol.3. 1-17. 